Marta Kocjan Barle

\title{
Sklanjanje starogrških in latinskih lastnih imen moškega spola po prvi sklanjatvi
}

\section{UVOD}

V slovenščini se pri prevzemanju tujih lastnih imen, med katera sodijo tudi starogrška in latinska imena, načeloma ravnamo po naslednjih pravilih: imena iz latiničnih pisav po pravilih Slovenskega pravopisa 2001 (dalje SP 2001) in slovenske slovnice načeloma ohranjamo v izvirni pisni obliki (SP 2001, \$ 172) ter jih glasovno in oblikoslovno prilagajamo slovenščini, iz nelatiničnih pisav pa jih prečrkujemo ter pisno, glasovno in oblikoslovno podomačujemo (SP 2001, $\$ 164,170$ in 180). Po spolu so prevzete besede moškega ali ženskega spola in se razvrščajo $\mathrm{v}$ moške ali ženske sklanjatve: imena bitij glede na svoj naravni, občna imena pa glede na slovnični spol - to pomeni, da odloča oblika in da zato po potrebi prevzetim besedam v slovenščini spol spremenimo (npr. fr. la chanson ž. sp. je v slovenščini zaradi ničte končnice šanson m. sp.). ${ }^{1}$ Enako velja nasprotno: tuji jeziki naša imena, redkeje občne besede, sprejemajo in preoblikujejo po svojih pravopisnih in slovničnih pravilih. To dokazuje tudi predlog prevajanja oz. polatinjenja naših krajevnih imen $\mathrm{v}$ latinščino $\mathrm{v}$ diplomski nalogi Renate Hrovatič Latinska imena slovenskih krajev. Imena, ki nimajo leksikalnega pomena in se jih ne da prevesti, se glasovno in oblikoslovno prilagodijo latinščini: ohranijo slovensko osnovo, že v imenovalniku dobijo npr. latinski -us (npr. Ormus za Ormož) in se v latinskem besedilu tudi sklanjajo po latinsko (npr. Ormus -ii), ne pa po slovensko (npr. Ormus -a).

$\mathrm{V}$ 1. moško sklanjatev sodijo samostalniki $s \mathrm{t}$. i. ničto končnico ${ }^{2}$ in nenaglašenim -o (npr. Kupído -a), -a (npr. Séneka -a, prednostno sicer 2.

»Prevod « spola, tj. šansona ž. sp., v rabi ni zaživel.

2 V Enciklopediji slovenskega jezika je končnica »/m/orfem za sklon /.../« (Toporišič, Enciklopedija slovenskega jezika, 85); ničta končnica (zapis ø) je »/k/ončnica, ki se izraža s prazno glasovno množico, ima pa iste lastnosti kakor glasovna« (op. cit., 145). 
sklanjatev: Séneka -e) in deloma -e (npr. Prenéste -a) in -u (npr. Papandreou -a). Ničto končnico imajo samostalniki na končni soglasnik, na nenaglašeni -i (npr. sirtáki -ja) in naglašene samoglasnike (npr. ró -ja) ter dvojnično na nenaglašena -u (npr. Papandreou -ja) in -e (npr. Prenéste -ja). Nenaglašena -e in -u imamo za netipično končnico. Končnica v stranskih sklonih se večinoma razlikuje od imenovalniške.

Antična imena so v tiskani (SP 2001) in elektronski izdaji Slovenskega pravopisa (dalje eSP 2003) označena kot grška in rimska; zaradi zapisa ali sklanjanja so omenjena $\mathrm{v} \$ 180,767-770,779,783,785,786$ ter v preglednicah pisav v $\$ 1073$ in 1107 . Glede na druga tuja imena so posebna po tem, da so izvirni -as, -es, -is, -os, -us, -um tudi v pravopisu ( ${ }^{\circ} S P 2003, \$ 767$ ) izjemoma imenovani končnice, v slovnici pa »stilno zaznamovane končnice« (Toporišič, Slovenska slovnica, 282).

Prenova pravopisa terja kritičen pregled posameznih tematskih sklopov, tudi starogrških in latinskih lastnih imen, predvsem tistih, ki bodisi niso zadovoljivo predstavljena bodisi niso dovolj izčrpno prikazana z zgledi, in presojo o tem, kako pravilno poimenovati t. i. končnice. $\mathrm{V}$ ta namen je bilo pregledanih 170 poslovenjenih starogrških (dalje st.gr.) in 81 latinskih imen (dalje lat.) moškega spola ${ }^{4}{ }^{\text {eSP }} 2003$, in sicer v Slovarju in Pravilih; ${ }^{5}$ vsa sodijo v 1. moško sklanjatev s sklanjatvenim vzorcem korák (Toporišič, Slovenska slovnica, 278), tista na končnico -a pa tudi v 2. moško sklanjatev s sklanjatvenim vzorcem vójvoda (Toporišič, Slovenska slovnica, 288). Pozornost v razpravi je namenjena imenom na izvirne končaje, ${ }^{6} \mathrm{v}$ pravopisu in slovnici omenjene kot končnice, medtem ko so druga, npr. Júpiter, Cézar, Stóbi, Pompêji, Pánteon, zaradi neproblematičnosti izpuščena. ${ }^{7}$ Ravno tako so izpuščene poosebitve, npr. Tánatos (Smrt), Fóbos (Strah), ali skupine mitoloških bitij, npr. st.gr. Gígantes > Gigánti, in množinski samostalniki (npr. Délfi, Pompêji).

Vsa imena so primerjana $\mathrm{z}$ oblikami v priročniku Bronislave Aubelj Antična imena po slovensko (dalje AIS); iz tega dela so dodana tudi nekatera imena, s katerimi je bilo mogoče zapolniti pravopisne vrzeli v sistemskem prikazu končajev. Ker v AIS ni razlag, jih je bilo po potrebi mogoče najti v Antiki. Večina imen je osebnih; od zemljepisnih imen so vključena tista, ki so tudi v AIS, npr. Ródos, Sámos, ne pa Santorín.

3 V priročniku Antična imena po slovensko (dalje AIS) je samo rodilnik Prenesta (AIS, XXV); po slovničnih in pravopisnih pravilih je možna tudi oblika Prenésteja (prim. »Borghése -a tudi Borghése -ja [borgeze] «v ${ }^{\mathrm{e} S P}$ 2003).

4 Mišljen je spol v slovenščini, ne v izvirnih jezikih: lat. Saguntum in Pantheon srednjega spola sta v slovenščini moškega spola.

$5 \mathrm{~V}$ eSP 2003 jih je mogoče najti z zahtevnim iskanjem. Razlage se v nekaterih primerih med seboj razlikujejo - poleg pridevnikov "grški« in »rimski« je v njih mogoče najti tudi »antični«, "perzijski«, »bizantinski« ali celo »atenski«, nekateri tipi razlag pa se povsem razlikuje od drugih (npr. pri Dioníziju je razlaga »tiran iz Sirakuz«, pri Brútu »zarotnik zoper Cezarja«).

6 Končaj je »/k/ončni del besede ne glede na morfemskost« (Toporišič, Enciklopedija slovenskega jezika, 85).

7 Mišljene so oblike, ne npr. stvarne napake: v geslu Júpiter ${ }^{1}$ je pomotoma razlaga »grški bog svetlobe in neba«. 
Običajno sodobno preverjanje rabe različnih oblik v korpusu Gigafida je v primeru antičnih imen le delno koristno, saj je zadetkov (dalje z.) za posamezna imena večinoma premalo; izjema so le pogosto rabljena, npr. Herkul (2644 z.) in Herkules (987 z.), Pitagora (343 z.) in Pitagoras (5 z.), Sofokles (192 z.), Sofoklej (130 z.), za npr. ime Aristotel/Aristoteles pa je težje razločiti med oblikama, razen v imenovalniku (Aristotel 1767 z. ${ }^{8}$ in Aristoteles 178 z.).

Prečrkovanje in prepis v razpravi sta povzeta po AIS - lat. npr. Saguntum in ne Săguntum -, končaji so zapisani fonetično, ne pa prečrkovano (npr. -is, ne -ys; -us, ne -ous). Razprava se v glavnem osredotoča na imenovalniške in rodilniške oblike $\mathrm{v}$ omenjenih priročnikih, ne na podomačevanje posameznih glasov in glasovnih skupin, ${ }^{9}$ zgodovinski pregled problematike, posredno prevzemanje starogrških imen iz latinščine ali morebitna manjkajoča imena; naglasno mesto je omenjeno le v primeru razhajanja med eSP 2003 in AIS. Na stvarne napake je opozorjeno na ustreznih mestih.

$\mathrm{V}$ eSP 2003 so antična imena predstavljena tako kot druga (iztočnica v imenovalniku in ob njej rodilniška končnica), le da pogosto z dvojnicami. Iz dvojnične oblike, označene $s$ »tudi«, naslovniku gotovo ni lahko razbrati rodilnika. V kakem primeru je mogoče naleteti celo na neskladje med pravilom in geslom v slovarskem delu. Na primer: $\mathrm{v} \$ 785$ je pravilo, da se $\mathrm{s} \mathrm{t}$ "podaljšujejo tudi nekatera grška imena $\mathrm{z}$ imenovalnikom na soglasnik: Ksenofon -ta, Ajas -anta. Pri teh imenih je daljša osnova pogostna že v imenovalniku.« Drugi obliki iz pravopisnega gesla »Ksenofónt -a m, im. tudi Ksenofón« bi težko pripisali rodilnik Ksenofónta, saj bi imenovalniku Ksenofón pritaknili zgolj rodilniško končnico in dobili Ksenofóna. Če bi ravnali drugače, potem bi morali npr. sklanjati Sófokles Sófokleja (prim. geslo »Sófoklej -a m s-em im. tudi Sófokles«).

$\mathrm{V}$ AIS je naveden samo imenovalnik, rodilnik pa le, če ni tvorjen iz poslovenjene imenovalniške oblike. Na dvojnice in zadrege, povezane z njimi, ${ }^{10}$ je opozarjal že Kajetan Gantar, ko je pisal o antičnih imenih v Slovenskem pravopisu iz l. 1962 in hkrati svetoval, »naj naš prihodnji pravopis pri antičnih imenih odpravi dublete in naj povsod uzakoni neko enotno obliko antičnega imena. In če je trend uradne slavistike tako usmerjen, naj bo to pač tista oblika, ki je že nekoliko udomačena. Toda poleg te oblike naj bo v oklepaju povsod navedena tudi izvirna oblika $v$ t.i. znanstveni transliteraciji. $\ll^{11}$

8 Pogosto je med njimi tudi Onassisovo ime.

9 Pravopisna pravila in pravila v AIS se ravnajo po načelih o pisanju prevzetih besed iz slovnice, v kateri je omenjeno, da se besede "grško-latinskega izvora « ravnajo po pravilih za zapisovanje besed iz "neevropskih jezikov« (Toporišič, Slovenska slovnica, 132).

10 "Vsekakor se mora za eno od dveh oblik odločiti, kajti vzporedno pojavljanje dveh različnih inačic istega imena $\mathrm{v}$ istem besedilu učinkuje nesistematično in neestetsko, lahko tudi neresno. Poleg tega lahko takšno pisanje, kot sem uvodoma omenil, zbudi pri nepoučenem bralcu vtis, da gre za dve povsem različni osebi. Kdor ne pozna jezikovnih zakonitosti, bo le težko uganil, da se za Aisopom in Ezopom skriva ista oseba." (Gantar, »Nekaj misli o pisavi antičnih imen in strokovnih izrazov", Arheološki vestnik 25, 541.)

11 Gantar, »Nekaj misli o pisavi antičih imen in strokovnih izrazov«, Arheološki vestnik 25, 542. 
$\mathrm{V}$ razpravi so antična imena razvrščena $\mathrm{v}$ dve poglavitni skupini: starogrška in latinska (antična) imena. V vsaki so potem razdeljena glede na starogrške in latinske končaje. Ti so prikazani v kombinaciji različnih skupin glasov (ne črk za te glasove, razen kadar so prekrivni). ${ }^{12}$ Zanje so uporabljeni naslednji črkovni simboli: $\mathrm{C}=$ soglasnik/konzonant, $\mathrm{V}=$ samoglasnik/vokal, $\mathrm{Zv}=$ zvočnik/sonant $(\mathrm{ZvZv}=$ zvočniški sklop $)$.

\section{STAROGRŠKA IMENA}

V eSP 2003 se večina starogrških lastnih imen moškega spola končuje na ničto končnico in sodi v 1 . moško sklanjatev.

\subsection{Starogrški končaj-as}

V eSP 2003 je 9 večzložnih imen s st.gr. končajem -as. Mogoče jih je razdeliti v tri skupine: 1. na st.gr. končaj -Cas (st.gr. Epaminóndas, Leonídas; Anaxagóras, Pythagóras, Protagóras), 2. na st.gr. končaj -Cias (Górgias, Teiresías) in 3. na st.gr. končaj-CVias (Aineías, Augeías). ${ }^{13}$

Zgledi iz prve skupine so v eSP 2003 predstavljeni različno: Epaminóndas ohranja -as, Leoníd ima dvojnico Leonídas. Rodilnika teh imen sta Epaminónda, Leonída. V AIS tudi ime Leónidas ${ }^{14}$ ohranja izvirni končaj, rodilnik je Leónida. Iz te skupine moramo izvzeti imena na končaj -goras, saj se je ustalila poslovenjena oblika na končaj -gora: imenovalnik Anakságora je v ${ }^{\text {SSP }} 2003$ enak kot v AIS; Pitágora in Protágora (taka sta tudi v AIS) imata dvojnici Pitágoras in Protágoras. Razlike med eSP 2003 in AIS so najopaznejše pri končaju -Cias: ${ }^{15}$ pravopisnih imenovalniških oblik Górgij in Tejrézij (v rodilniku Górgija in Tejrézija) v AIS ni, tu sta imenovalnika enaka dvojničnim $\mathrm{v}$ pravopisu, tj. Górgias in Tejrézias, razlika med priročnikoma pa je tudi v pisni podobi rodilnika: Górgija in Tejrézija ( ${ }^{\mathrm{C} S P} 2003$ ) proti Górgia in Tejrézia (AIS).

Poslovenjeni obliki iz 3. skupine sta Ávgij in Enêj (končaj-CVij), tako kot je tudi v AIS.

V AIS je poslovenjeno ime Arísteas -tea iz st.gr. oblike Aristéas (končaj -Céas), v eSP 2003 ga ni.

12 Npr.: Za Pýrrhos je primeren zapis -VCos (ne -VCCCos).

13 Ta imena moramo razlikovati od tistih na končaj -s (gl. točko 2.7.), katerih imenovalnik tvorimo iz st.gr. rodilniške osnove na -nt- (npr. st.gr. Aías > poslov. Ajánt).

14 Razlika med AIS in ${ }^{e} S P 2003$ je tudi v naglasu Leónidas in Leonídas.

15 Zgledov z drugimi samoglasniki v končaju v eSP 2003 ni. Iz AIS sodi med končaje -CVas končaj -eas z ohranjenim st.gr. -as kot delom imenovalniške osnove (npr. Arísteas z rodilnikom Arístea). 
2.1.1. Predlog za slovenjeni imenovalnik in sklanjanje

- V st.gr. končaju -Cas (razen -goras) dvo- in večzložnih imen st.gr. -as ohranjamo kot del osnove, imenovalniška končnica je ničta: Mídas > Mídas - $a,{ }^{16}$ Epameinóndas > Epaminóndas -a, Leonídas > Leónidas -a.

- St.gr. končaj -goras slovenimo v -gora, imenovalniška končnica je -a: Pythagóras $>$ Pitágora -e in -a (2. in 1. moška sklanjatev).

- St.gr. končaj -Cias slovenimo v -Cij, imenovalniška končnica je ničta: Gorgías > Górgij-a, Teiresías > Tejrézij-a.

- St.gr. končaj-CVias slovenimo v -CVij, imenovalniška končnica je ničta: Augeías (lat. Augias) > Ávgij-a, Aineías (lat. Aeneas) > Enêj-a.

- St.gr. končaj-Céas slovenimo v-Cej: Aristéas $>$ Arístej -a.

\subsection{Starogrški končaj-es}

V eSP 2003 je 38 st.gr. imen z izvirnim končajem -es, od teh so v izvirni obliki dvozložna štiri (st.gr. Áres, Háides, Hermês in Thalês). ${ }^{17}$ Po st.gr. končaju lahko večbesedna delimo v dve skupini: 1. na st.gr. končaj-(V)Ces (npr. Demosthénes) in 2. na st.gr. končaj -kles, tj. končaj-CCes (npr. Periklês). V e'SP 2003 so večzložna imena iz obeh skupin poslovenjena neenotno. Pet imen na st.gr. končaj -VCes ali -CCes je bodisi brez st.gr. -es, tako kot je tudi v AIS - Apél, Evklíd, Filoktét, Parménid, Polinêjk -, ali pa sta, kar pri 22 imenih, možni dve obliki: prednostna brez st.gr. končaja -es (Ahil, Alkibíad, Arhiméd, Aristófan, Aristótel, ${ }^{18}$ Artaksêrks, Demósten, Diógen, Eratósten, Evrípid, Ganiméd, Hád, Hêrkul, Hipókrat, Láert, Miltiád, Orést, Orígen, Praksitel, Prokrúst, Sókrat, Tukídid) in možna z oznako »tudi « (Ahíles, Alkibíades, Arhimédes, Aristófanes, Aristóteles, Artaksêrkses, Demóstenes, Diógenes, Eratóstenes, Evrípides, Ganimédes, Hádes, Hêrkules, Hipókrates, Láertes, Miltiádes, Oréstes, Orígenes, Praksiteles, Prokrústes, Sókrates, Tukidídes) - v AIS so vsa brez st.gr. -es.

V AIS je v vseh imenih na st.gr. končaj -kles -es ohranjen, rodilniški končaj je -kla. Tak je v eSP 2003 samo en zgled, in sicer Empédokles -kla, štiri imena imajo poslovenjeni končaj -klej (Dámoklej, Hêraklej, Sófoklej, Temístoklej) in dvojnico z -es kot delom osnove (Dámokles, Hêrakles, Sófokles, Temístokles), samo na -klej je Pêriklej, povsem drugačno obliko ima Pátrokel, z različico Pátrokles, rodilnik obeh oblik je Pátrokla.

16 Zgledov za dvozložna imena na -as v eSP 2003 ni, razen imena Mítra, ki je v ${ }^{e} S P 2003$ razložen samo kot "perzijski bog svetlobe«, iz tega kulta pa je izšel tudi grško-rimski kult (st.gr. Míthras, v obeh priročnikih Mítra).

$17 \mathrm{~V}$ eSP 2003 je poslovenjena oblika Táles iz Miléta, v AIS in leksikonu Harvey, Antika, je navedeno samo ime Táles.

18 V rabi je tudi sklanjanje Aristótel Aristótla, tako kot v ${ }^{\mathrm{e}} \mathrm{SP} 2003$ Pátrokel Pátrokla. 


\subsubsection{Predlog za slovenjeni imenovalnik in sklanjanje}

- V dvozložnih imenih st.gr. končaj -es ohranjamo kot del poslovenjene osnove, imenovalniška končnica je ničta: Áres - $a$.

- V večzložnih imenih na st.gr. končaj -VCes ${ }^{19}$ ali -CCes st.gr. končaj -es opuščamo, imenovalniška končnica je ničta: Aristótel -a, Evklíd -a, Orést -a.

- V st.gr. končaju -kles oz. -ZvZves ${ }^{20}$ st.gr. -es ohranjamo kot del osnove, imenovalniška končnica je ničta: Empédokles - $a$, Sófokles - $a$, Pêrikles - $a$, Pátrokles - $a$; Artafêrnes - $a$. Zaradi ustaljenega pregibanja teh imen predvsem v strokovnih krogih (npr. Empédokles -kla, Sófokles -kla, Pêrikles -kla, Pátrokles -kla; Artafêrnes -rna) bi lahko imeli -es tudi za stilno zaznamovano imenovalniško končnico in v pravopisu dvojnico $\mathrm{z}$ ustrezno oznako. ${ }^{21}$

Vprašanje je, kaj storiti s tretjo obliko na poslovenjeni končaj -klej, ki je v rabi lahko enako pogosta kot na -kles (npr. Heraklej ima v Gigafidi 369 (z.), Herakles pa 213).

\subsection{Starogrški končaj -is}

V 'SP 2003 so tri poslovenjena dvozložna (Dáfnis, Páris in Téspis) in eno večzložno ime (Radamántis); st.gr. končaj -is ${ }^{22}$ je del osnove (enako v AIS), ${ }^{23}$ končnica pa je ničta. Rodilnik teh imen je Dáfnisa, Párisa, Téspisa, Radamántisa.

\subsection{Starogrški končaj-os}

V eSP 2003 je 83 imen na st.gr. končaj -os. Od tega je 15 dvozložnih imen, ki ohranjajo st.gr. -os kot del poslovenjene osnove (Átos, Délos, Êros, Fóbos, Híos, Lézbos, Mílos, Mínos, Náksos, Pátmos, Plútos, Ródos, Sámos); dve st.gr. imeni Pýrrhos in Ploûtos sta brez -os (Pír in Plút ${ }^{2}$ ) ali st.gr. končaj ohranjata (Píros in Plútos), v AIS sta poslovenjeni obliki Pír in Plútos. St.gr. imeni Kýrrhos in Týros sta poslovenjeni v Kír in Tír. Po AIS, XIV, »/o/krajšujemo samo tista dvozložna imena na -es in -os, ki se potem v podomačenih oblikah končujejo na -jt, -nt, -rt, -st in -vt (Proitos Projt, Xanthos Ksant, Parthos Part, Sestos Sest,

$19 \mathrm{~V}$ to skupino sodi tudi zapis enega soglasnika $\mathrm{z}$ dvema črkama (npr. st.gr. Seuthes $>$ Sevt). Prim. tudi op. 12.

20 Ime Artafêrnes s končajem -rnes (-ZvZves), ki ima rodilnik Artafêrna; rm (med zgledi je navedeno ime z rn Artafernes) je v AIS, XIV, »neizgovorljiv soglasniški sklop«. Nobeno od teh imen zaradi soglasniškega sklopa, katerega del je zvočnik (npr. l), ali zvočniškega sklopa rn v izglasju ne bi v slovenščini povzročalo nikakršnih pisnih in izgovornih težav, če bi jih zapisali v skrajšani obliki, npr. ${ }^{\star}$ Sofokl (kot Trakl) ali ${ }^{\star}$ Artafern (kot Saturn), vendar teh oblik v rabi ni.

21 Med zdaj navedenimi ( ${ }^{\text {SS }}$ 2001, XII) bi ustrezala oznaka »in«, ki »uvaja nekoliko manj navadno dvojnico« ('SP 2003, \$ 1066) ali »izobr.«, tj. izobrazbeno, »knjižna prvina, značilna za ljudi, ki v svojem izražanju kažejo na določeno višjo izobrazbo« ( ${ }^{S} S P$ 2003, \$1060).

22 Zapisan je lahko tudi kot -ys.

23 V AIS je oblika brez -is, tj. Radamant, kazalka na Radamantis. 
Seuthes Sevt), ${ }^{24}$-jz in -rz (Kroisos Krojz, Tarsos Tarz), -kh, -ks in -ps (Bakchos Bakh, Xerxes Kserks, Thapsos Taps). Izjemoma se okrajšajo tudi nekatera druga dvozložna imena (Kyrrhos Kir, Pýrros Pir, ${ }^{25}$ Phoibos Fojb) «. ${ }^{26}$ Pravilo je precej zahtevno; poleg tega v njem, kakor je mogoče razbrati iz zgledov v slovarskem delu (npr. Lýktos > Líkt in Lýndos > Línd), manjkata soglasniška sklopa -kt in -nd.

Precej več (vsega skupaj 64) je v eSP 2003 večzložnih imen na st.gr. končaj -os. Tudi ta so poslovenjena neenotno. V 1. skupino sodi 26 imen (in eden v

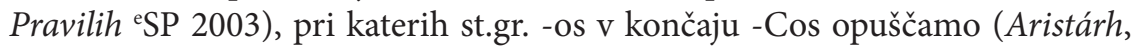
Demókrit, Dioníz, Éfez, Éol, Epír, Epikúr, Ézop, ${ }^{27}$ Farzál, Halikarnás, Heliodór, Heraklit, Heródot, Homêr, Korínt, Likúrg, ${ }^{28}$ Lizip, Lukiján, Milét, Narcís, Olímp, Parnás, Peloponéz, Polifém, Titán, Urán $\left.{ }^{1}\right)$.

$\mathrm{V}$ 2. skupini je 23 imen, pri katerih ga bodisi opuščamo (Ájshil, Darêj, Dédal, Diofánt, Galén, Héfajst, Heróstrat, Heziód, ${ }^{29}$ Hipárh, Íkar, Kalimah, Okeán, ${ }^{30}$ Píndar, Plotín, Plútarh, Príam, Sízif, Tántal, Tártar, Télemah, Teofrást, Tróil, Zóil) ali ga ohranjamo kot del poslovenjene osnove ${ }^{31}$ (Ájshilos, Daréios, Dédalos, Diofántes, ${ }^{32}$ Galénus, ${ }^{33}$ Héfajstos, Heróstratos, Heziódos, Hipárhos, Íkaros, Kalímahos, Okéanos, Píndaros, Plotínos, Plútarhos, Príamos, Sízifos, Tántalos, Tártaros, Télemah, Teofrástos, Tróilos, Zóilos). Vsa ta imena so v AIS brez st.gr. končaja -os.

Popolnoma drugače sta poslovenjeni st.gr. imeni Polýkleitos in Períkleitos: Poliklêj in Pêriklej.V AIS je od Poliklit usmerjeno na Poliklêjt, od Periklit na Periklêjt.

St.gr. -os v končaju -VVros je v imenu Minótauros v poslovenjeni obliki opuščen (Minotáver), v imenu Epídauros pa je opuščen (Epidáver) ali je del osnove (Epidávros). V AIS je v obeh primerih opuščen, Epidavros je kazalka. Zgledov na st.gr. končaj -CCros v eSP 2003 ni, v AIS so brez st.gr. končaja -os (npr. st.gr. Anaxímandros in Ménandros sta Anaksimánder in Menánder). V zgledih na st.gr. končaj-ZvZvos je v AIS st.gr. -os ohranjen, rodilnik pa je na -ZvZva: Epidámnos -mna, Mimnêrmos -rma. ${ }^{34}$

$\mathrm{V}$ eSP 2003 je 8 imen na st.gr. končaj -CVos, od tega je le eno na -laos $(-\mathrm{ZvVos}),{ }^{35}$ in sicer $\mathrm{v}$ dveh poslovenjenih oblikah: Meneláj (poslovenjeni končaj-CVj) in Meneláos; druga imajo v končaju samoglasnik i, torej-Cios,

24 Prim. tudi op. 19.

25 V slovarskem delu je ime zapisano s h-jem: Pýrrhos.

$26 \mathrm{~V}^{\text {eSP }} 2003$ je poslovenjeni imenovalnik Féb (»Féb -a m, im. tudi Fébus oseb. i. (ẹ) Apolon«) iz lat. Phoebus (\$1073), v AIS je od te oblike usmerjeno na Fojb iz st.gr. Phoîbos.

27 V AIS je naglas na o: Ezóp.

$28 \mathrm{~V}$ eSP 2003, $\$ 1073$, je navedeno: Likúrg/Likúrgus za st.gr. Lykoûrgos.

29 V AIS je naglas na i: Hezíod.

$30 \mathrm{~V}$ AIS je naglas na e: Okéan.

$31 \mathrm{~V}$ eSP 2003, $\$ 767$, je samo oblika Arhilohos.

32 Ime je napačno zapisano: st.gr. Dióphantos > poslov. Diofánt (AIS, 51).

$33 \mathrm{~V}$ eSP 2003 je pomotoma razložen kot »rimski zdravnik«, od tod tudi končaj -us namesto -os.

34 Zaradi zvočniške skupine bi bili mogoči obliki ${ }^{\star}$ Epidamn in ${ }^{\star}$ Mimnerm; prim. op. 20.

35 V AIS je takole pravilo: »Imena na -laos in -raos podomačujemo s končnima -laj in -raj: Menelaos Menelaj, Amphiaraos Amfiaraj.« Ni jasno, zakaj naj bi druga imena na -Caos in -Coos (AIS, XIV) prevzemali skupaj s končajem, npr. »Oinomaos Ojnomaos, Peirithoos Pejritoos, v rodilniku pa imeli Ojnómaa in Pejrítoa, in zakaj ne tako kot tista na -laos in -raos, torej Ojnómaj (tako še npr. Danaós > Dánaj, Kládaos > Kládaj). 
poslovenjen v -Cij (Apolónij, Asklépij, ${ }^{36}$ Dionizij, Evzébij, Porfírij); dve imeni poleg podomačene oblike (Hélij, Políbij) ohranjata v imenovalniku tudi st.gr. končaj -os kot del osnove (Hélios, Políbios). V AIS so vsa ta imena navedena v podomačeni obliki s poslovenjenim končajem -CVj in $-\mathrm{ZvVj}$.

V eSP 2003 so tri imena na st.gr. končaj -Vîos: Alkaîos, Dareîos, Ptolemaîos. Poslovenjeni končaj v imenovalniku je bodisi -CVj (Alkáj) ali -ZvVj (Darèj, ${ }^{37}$ Ptolemáj) bodisi -CVjos (Alkájos) ali-ZvVjos (Ptolemájos); eno ime (Daréios) ohranja st.gr. končaj kot del poslovenjene osnove.

\subsubsection{Predlog za slovenjeni imenovalnik in sklanjanje}

- V dvozložnih imenih st.gr. -os v st.gr. končaju -VCCos opuščamo, imenovalniška končnica je ničta: Proîtos $>$ Prójt -a, Sestós $>$ Sést-a, Lýktos $>$ Likt-a, Líndos > Lind -a.

- V dvozložnih imenih st.gr. -os v st.gr. končaju -VCos ohranjamo kot del osnove, imenovalniška končnica je ničta: Mínos - $a$, Líkos - a. Izjemoma ga opuščamo: Kír - a, Pír - a, Tír - a.

- V večzložnih imenih st.gr. -os v st.gr. končaju -Cos opuščamo, imenovalniška končnica je ničta: Aischýlos $>$ Ájshil-a, Polýkleitos $>$ Poliklêjt -a, Epídauros > Epidáver -vra.

- V st.gr. končaju -ZvZvos st.gr. -os ohranjamo kot del osnove, imenovalniška končnica je ničta: Epídamnos > Epidámnos -a, Mímnermos $>$ Mimnêrmos - a.

- St.gr. končaje -CVos in -ZvVos ter -CVîos in -ZvVîos slovenimo v-CVj in - $\mathrm{ZvVj}$, imenovalniška končnica je ničta: Danaós $>$ Dánaj-a, Peiríthoos $>$ Pejritoj-a; Menélaos > Meneláj-a, Amphiáraos > Amfiaráj-a, Hélios > Hélij -a; Alkaîos > Alkáj-a, Ptolemaîos > Ptolemáj-a.

\subsection{Starogrški končaj-us}

V eSP 2003 je 11 imen na st.gr. končaj -us; ta je sestavina st.gr. končaja -Ceús. Od dvozložnih v stari grščini je eno ime (Zeús $>$ Zévs). V petih imenih je st.gr. končaj -Cus poslovenjen v-Cej (Ántej, ${ }^{38}$ Egêj, ${ }^{39}$ Pelêj, Perzêj, Pirêj), pet jih ima poleg oblik na končaj -Cej (Odisêj, Órfej, Prometêj, Prótej, Tezêj), ki je iz st.gr. rodilnika, še oblike, v katerih je -us del osnove (Odíseus, Órfeus, Prometéus, Próteus, Tezêus). V AIS imajo vsa ta imena poslovenjeni končaj-Cej. ${ }^{40}$

Od teh imen se razlikuje poslovenjena oblika Ojdip, ki ima dvojnico Ojdípus. V AIS je Ojdipus kazalka na Ojdip (< Oidipos /Oidipous/).

36 Kazalka na Eskulap. 


\subsubsection{Predlog za slovenjeni imenovalnik in sklanjanje}

St.gr. končaj -Ceús slovenimo v -Cej, imenovalniška končnica je ničta: Aigeús $>$ Egêj-a, Odysseús > Odisêj -a, Aristeús > Aristêj -a.

\subsection{Starogrški končaj-on}

V eSP 2003 je 24 imen na st.gr. končaj -on. ${ }^{41}$ Nobenih razlik pri prevzemanju v slovenščino in pregibanju ni med dvo- ali večzložnimi imeni na st.gr. končaj -Con ${ }^{42}$ (Drákon, Háron, Jázon, Míron, ${ }^{43}$ Pártenon, Píron, Pláton, Strábon, ${ }^{44}$ Plúton ${ }^{1}$, Tríton, Zénon; Agamémnon, Apólon, Lakedemón, ${ }^{45}$ Pergamón, ${ }^{46}$ Pozêjdon) ali -CVon (Orion ${ }^{1}$, Pigmálion), ravno tako ne med eSP 2003 in AIS. Drugače je le v primerih, ko imajo st.gr. imena rodilniško osnovo na -nt- ${ }^{47} \mathrm{~V}$ slovenjenih oblikah pa naj bi bil -nt tudi del imenovalniške osnove. V eSP 2003 je tako zapisan Anákreont, ${ }^{48}$ ravno tako so v tej obliki Kréont, ${ }^{49}$ Ksenofónt in Laokoónt, vendar vsi tudi s končajem -on $\mathrm{v}$ imenovalniku, tj. Kréon, Ksenofón in Laokoón; pri imenu Áheron (st.gr. rodilnik je Acherontos) je rodilnik bodisi Áherona bodisi Áheronta. Ta imena so v AIS predstavljena enotno: oblike na -on so kazalke na oblike na -ónt. ${ }^{50}$

St.gr. končaj -Vsion je v eSP 2003 in AIS slovenjen v-Vzij (Elízij). Zgledov na st.gr. končaj -CVion, ki je v AIS poslovenjen v-CVjon (npr. Pédaion > Pedájon, Herákleion > Heraklêjon), v eSP 2003 ni.

\subsubsection{Predlog za slovenjeni imenovalnik in sklanjanje}

- V st.gr. končajih -Con in -CVon -on ohranjamo kot del poslovenjene osnove, imenovalniška končnica je ničta: Jázon > Jázon -a, Pygmalíon > Pigmálion - $a$.

- Imena, ki imajo v st.gr. rodilniku osnovo na -nt- (razen izjeme Drákon), slovenimo tako, da je -nt- del imenovalniške osnove, končnica je ničta: Achéron Achérontos $>$ Aherónt -a, Xenophôn Xenophóntos $>$ Ksenofónt - a.

- St.gr. končaj -Vsion slovenimo v -Vzij, imenovalniška končnica je ničta: Elýsion > Elízij -a.

- St.gr. končaj -CVion slovenimo v -CVjon, imenovalniška končnica je ničta: Herákleion > Heraklêjon $-a$.

41 Kot končnica je omenjena v AIS, XV, in sicer v končajih -aion, -eon, -eion in -ion.

42 Za st.gr. Gárgaron je v AIS mogoče najti poslovenjeno obliko Gárgar (AIS, XIV in 81).

43 Ime naj bi imelo premični naglas: Míron -óna.

44 Ime naj bi imelo premični naglas: Strábon -óna.

45 V AIS se imenovalnik glasi Lakedájmon.

46 V AIS je naglas na e: Pêrgamon.

47 To ne velja za st.gr. ime Drákon s st.gr. rodilnikom Drákontos.

48 Predvideno je premično naglaševanje, torej Anákreont -ónta, v AIS je naglas že v imenovalniku na o: Anakreónt.

49 V AIS je naglas na o: Kreónt.

50 V slovarskem delu AIS je tako ime tudi Pteleónt, ki pa je v uvodnem delu (AIS, XV) navedeno kot Pteleon in našteto med tistimi imeni "na -aion, -eon in -eion ter večin/o/ dvo- in trozložnih imen na -ion«, ki ohranjajo »izvirno končnico in se skupaj z njo tudi sklanjajo«. 
2.7. Starogrški končaj-s

Čeprav imajo nekatera st.gr. imena pred končnim -s samoglasnik a, i ali u, jih moramo razlikovati od tistih na končaje -as, -is, -us. To velja za tista, ki imajo st.gr. rodilniško osnovo na -nt- (npr. Aías Aiantos). V eSP 2003 sta taki imeni samo dve ${ }^{51}$ in sicer Ajánt $\mathrm{z}$ dvojničnim imenovanikom Ájas, in Atlánt, na katerega je usmerjeno od iztočnice Átlas. Oba zgleda in še drugi te vrste so v AIS obravnavani enotno, tj. $\mathrm{z}$-nt kot sestavino poslovenjene imenovalniške osnove.

\subsubsection{Predlog za slovenjeni imenovalnik in sklanjanje}

Imena, ki imajo v st.gr. rodilniku osnovo na -nt-, slovenimo tako, da je -nt- del imenovalniške osnove, končnica je ničta: Aías > Ajánt -a, Átlas > Atlánt -a.

\section{LATINSKA IMENA}

V eSP 2003 se večina latinskih (antičnih) lastnih imen moškega spola končuje na ničto končnico in sodi v 1 . moško sklanjatev, šest jih ima končnico -a (Agrípa, Kalígula, Karakála, Katilína, Senéka, Súla) in se sklanjajo po 2. (Agrípa -e) ali 1. moški sklanjatvi (Agrípa-a), eden se končuje na -o (Kupído). ${ }^{52}$

\subsection{Latinski končaj-us}

V eSP 2003 je 62 imen na lat. končaj -us. Od dvozložnih imen je v eSP 2003 samo en zgled z zgolj ohranjeno lat. končnico (Jánus). Drugih šest jih v imenovalniku bodisi ne ohranja lat. končaja -us (Bákh, Brút, ${ }^{53}$ Fávn, Féb, ${ }^{54}$ Grákh, Plávt, Tít) bodisi ga ohranja (Bákhus, tudi Bákhos, ${ }^{55}$ Brútus, Fávnus, Fébus, Grákhus, Plávtus, Títus). Vsa ta imena so v AIS v poslovenjeni obliki brez -us.

V slovarskem delu eSP 2003 je 22 večzložnih imen na lat. končaj -Cus: 13 jih je tako kot v AIS brez lat. -us (Diokleciján, Domiciján, Donát, Germánik, Hádrijan, ${ }^{56}$ Neptún ${ }^{1}$ Oktaviján, Palatín, Pilát, Tácit, Úlpijan, ${ }^{57}$ Vespazijàn,${ }^{58}$ Vulkán), devet jih je v dveh oblikah: brez lat. -us (Katúl, Lukán, Lukúl,

$51 \mathrm{Na}$-s se končuje tudi ime reke Stíks, ki je v slovenščini, v nasprotju s staro grščino, moškega spola.

52 Drugi zgledi so možni samo kot različice, npr. Cicero (prim. točko 3.3.).

$53 \mathrm{~V}$ razlagi »zarotnik zoper Cezarja « ni besede »rimski«, zato imena Brut z zahtevnim iskanjem v

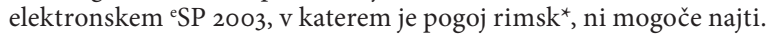

54 Usmerjeno na Apolon; prim. op. 26.

55 »Bákh (Bákhos, lat. Bacchus)/,/ drugo ime (verjetno lidijskega izvora) za grškega boga *Dioniza in njegovo običajno ime v latinščini.« (Harvey, Antika, 75.)

56 V AIS je naglas na drugem a: Hadriján.

$57 \mathrm{~V}$ AIS je to ime naglašeno na a: Ulpiján.

58 Pomotoma ima ime kratko naglašeni a, v rodilniku premenjenega z dolgim (Vespazijàn -ána), in odvečno dvojnico z dolgim a (Vespaziján). 
Navpórt, Rém, Rómul, Saturn ${ }^{1}$ /končaj-Vrnus/, Sevêr, Traján) in z lat. -us kot delom osnove (Katúlus, Lukánus, Lukúlus, Naupórtus, Rémus, Rómulus, Sevêrus, Satúrnus, Trajánus). V eSP 2003, \$1073, so v poglavju Latinska pisava navedeni še Kvirín/Kvirínus in pomotoma st.gr. Lykoûrgos kot Likúrg/Likúrgus. V AIS so vsa ta imena brez končaja -us.

Imen na lat. končaja -Cius in -CCius je v slovarskem delu 28, v Pravilih pa tri. Vsa, razen imen Bélizar ${ }^{59}$ in Merkúr ${ }^{1}$ ter Ovíd in Vergíl (kot prednostna različica), imajo poslovenjeni končaj-Cij (Antónij, Avrélij, Boétij, ${ }^{60}$ Lívij, Márk Avrélij, ${ }^{61}$ Svetónij, Teodózij, v Pravilih, $\$ 1073$, še Sékstij), drugih 12 poleg poslovenjene oblike (Aétij, Fábij, Flávij, Kásij, Petrónij, Plínij, Salústij, Tibêrij, Vergílij, ${ }^{62}$ Vitrúvij, v Pravilih, $\$ 1073$, še Evgénij, Sekstílij) tudi lat. končaj -Cius kot del osnove (Aétius, ${ }^{63}$ Fábius, Flávius, Kásius, Petrónius, Plínius, Salústius, Tibêrius, Vergílius, Vitrúvius, v Pravilih, $\$ 1073$, še Evgénius, Sekstílius), imena na lat. -tius (razen -stius) pa bodisi poslovenjeni -cij (Lukrécij, Póncij, Propêrcij) ali poleg te oblike (Horácij, Teréncij) tudi dvojnice na -cius (Horácius, Teréncius). Vsa ta imena, razen Belizárja in Merkúrja, imajo v AIS poslovenjeni končaj-Cij (za -tius pa -cij). Lat. ime Eustachius (končaj-Cius) je v eSP 2003 poslovenjeno v Evstáhij, ${ }^{64}$ v AIS in v leksikonu Antika ga ni.

$\mathrm{V}$ eSP 2003 je slovenjeno samo eno ime $\mathrm{z}$ lat. pisnim končajem -CVius: Pompeius - Pompêj z dvojnično obliko Pompêius. V AIS je ta končaj poslovenjen v -CVj, torej so to ime in podobna druga (npr. Caius, Cnaeus / Gnaeus/, Apuleius) poslovenjena v Pompêj, Gáj, Gnéj, ${ }^{65}$ Apulêj.

\subsubsection{Predlog za slovenjeni imenovalnik in sklanjanje}

- V dvo- in večzložnih imenih lat. -us v končaju -Cus opuščamo, imenovalniška končnica je ničta: Bacchus (st.gr. Bákchos) > Bákh -a, Quirinus $>$ Kvirín - a, Plautus > Plávt - $a$.

- Lat. končaja -Cius in -CCius (tudi -stius) slovenimo v-Cij in -CCij (tudi -stij), -tius v -cij (razen -stius) - vsi iz lat. rodilnika -, imenovalniška končnica je ničta: Vergilius > Vergílij-a, Lucretius > Lukrécij-a, Salustius > Salústij-a.

- Lat. končaj -CVius slovenimo v-CVj (iz lat. rodilnika), imenovalniška končnica je ničta: Apuleius > Apulêj-a, Pompeius > Pompêj-a.

\footnotetext{
59 V AIS je ime naglašeno na a: Belizár.

60 V AIS je oblika Boecij kazalka, iztočnica je Boétij.

61 Obe imeni, Avrélij in Márk Avrélij, imata enako razlago: "rimski cesar«.

62 Usmerjeno na iztočnico Vergil.

63 Aétij je po AIS poslovenjen iz st.gr. Aétios, ne pa lat. Aetius, saj bi končaj -tius v tem položaju slovenili v -cij: ${ }^{\star} A e c i j$.

64 Mišljen je Makrobijev sin. V AIS in v leksikonu Harvey, Antika, 338, je Makróbij geslo, v geselskem članku je samo govor o sinu, imena ni.

65 Pravilni naglas: Gnêj.
} 


\subsection{Latinski končaj-um}

V eSP 2003 je šest imen z lat. končajem -um, od teh se dve končujeta na -Cum: ${ }^{66}$ eno ohranja -um kot del osnove (Neviodúnum), drugo je bodisi brez lat. -um (Sagúnt) in z ohranjenim končajem kot delom imenovalniške osnove (Sagúntum). ${ }^{67} \mathrm{~V}$ AIS sta obe imeni brez -um (Sagúnt in Neviodún). Druga se končujejo na -CVum: lat. Latium (končaj -tium) je slovenjen v Lácij (končaj -cij), Capitolium v Kapitól, ${ }^{68}$ Colosseum v Kolosêj, ${ }^{69}$ Herculaneum pa v Herkulánej. Zgledov za pisni končaj -CVVum v eSP 2003 ni, v AIS je npr. zgled za lat. končaj -Caeum (polatinjeni st.gr. -Caion) ime Lilybaeum (st.gr. Lilýbaion) s slovenjenim končajem -Cej (iz lat. rodilnika): Lilibêj.

\subsubsection{Predlog za slovenjeni imenovalnik in sklanjanje}

- Lat. -um v lat. končaju -Cum opuščamo, imenovalniška končnica je ničta: Sagúnt -a.

- Lat. končaj -CVum slovenimo v -CVj (iz lat. rodilniške osnove): Herculaneum > Herkulánej -a, Lilybaeum (st.gr. Lilýbaion) >Lilibêj -a; lat. -tium slovenimo v -cij: Latium > Lácij-a.

\subsection{Latinski končaj-o}

V eSP 2003 je sedem imen na lat. končaj -o: tri imajo imenovalnik iz lat. rodilniške osnove (Nero Neronis), torej se končujejo na -on: Nêron ${ }^{70}$ ter Rúbikon in Trimálhion s premičnim naglaševanjem (Rubikóna, Trimalhióna), tako kot je tudi v AIS. Druga tri imena imajo dvojne oblike: slovenjeni imenovalnik iz lat. rodilniške osnove (Cíceron, Káton in Scípion) in končaj -o kot del imenovalniške osnove (Cícero, Káto in Scípio) ter v obeh primerih enak rodilnik in premično naglaševanje (Ciceróna, Katóna in Scipióna). ${ }^{71} \mathrm{~V}$ AIS je samo slovenjena oblika Káton, poslovenjeni Scípion ima premično naglaševanje, ravno tako Cícero, na katerega je usmerjeno od Ciceron. Lat. Cupido (rodilnik je Cupidinis) je v eSP 2001 in v AIS poslovenjen v Kupído.

66 V AIS je mdr. zgled z lat. končajem -CCum (natančneje -CZvum), ki v poslovenjenem imenovalniku ohranja lat. -um kot del imenovalniške osnove (Velabrum), v rodilniku pa ga zamenjuje s končnico -a (Velabra). Po podobnosti s st.gr. imeni na končaj -CZvos (v AIS npr. st.gr. Anaksimandros), katerih končaj je poslovenjen v-CeZv (Anaximánder-dra), bi tudi lat. končaj -CZvum lahko slovenili v-CeZv: Veláber-bra; prim. op. 20 o soglasniških in zvočniških sklopih.

$67 \mathrm{~V}$ latinščini je to ime srednjega spola, v slovenščini so tuja imena na soglasnik moškega spola. Slovenski rodilnik naj bi se glasil Sagúnta; prim. op. 4.

68 V AIS je Kapitol kazalka, iztočnica za lat. obliko Capitolium je Kapitólij, ki je v opombi razložen kot »/n/ajvišja točka Kapitolina s svetiščem, pogosto tudi cel grič« (AIS, 110).

69 V AIS ga ni, v leksikonu Harvey, Antika, je.

70 V AIS je napačno naglasno znamenje: Néron.

71 O nerodnosti razbiranja rodilnika iz dvojnic gl. 1. Uvod. V Novi besedi je 22 z. za rodilnik Cicera, en z. za Scipia in nobenega za Kata. 


\subsubsection{Predlog za slovenjeni imenovalnik in sklanjanje}

Imenovalnik tvorimo iz lat. rodilniške osnove, končnica je ničta, naglas pa nepremični in tudi premični: Cíceron-a tudi Cíceron -óna, Trimálhion-a tudi Trimálhion -óna.

\subsection{Latinski končaj-s}

V eSP 2003 je pet imen na lat. končaj -s: enozložno Márs; lat. Maecenas je poslovenjen v Mecén, ob njem je mogoča tudi oblika Mecénas; za dvozložno ime Nepos je v Pravilih, $\$ 770$, rečeno, da »se od rodilnika naprej osnova lahko neobvezno premenjuje (Nepos Nepota) «. V AIS sta oba imenovalnika tvorjena iz lat. rodilniške osnove: Mecenát (< lat. rod. Maecenatis) in Nepót (< Nepotis). Lat. Juvenalis je poslovenjen v Juvenal, tako kot v AIS, kjer je tole pravilo: »Imen s samoglasniško osnovo na -is in -es navadno ne spreminjamo; izjeme so le osebna imena na -alis: Martialis Marcial.« (AIS, XVI.) Lat. ime Valens ostaja v ${ }^{\text {eSP }} 2003$ in AIS kljub lat. rodilniku Valentis nespremenjeno (Válens).

\subsubsection{Predlog za slovenjeni imenovalnik in sklanjanje}

- Imenovalniška oblika Mecén se je, tudi zaradi občnega imena mecén, že toliko uveljavila, da je ne bi bilo smiselno samo zaradi sistemske rešitve spreminjati. Lat. ime Nepos tvorimo iz rodilniške osnove, imenovalniška končnica je ničta: Nepót $-a$.

- Imena na lat. končaj -alis slovenimo v -al: Juvenalis > Juvenál -a.

\section{SKLEP}

Prevzemanje antičnih, predvsem starogrških imen, se od prevzemanja drugih imen zaradi zgodovinskih in (jezikovno)kulturnih razlogov razlikuje predvsem v upoštevanju vpliva izvorne sklanjatve na slovensko in možnosti premičnega naglaševanja. Stara grščina in latinščina sta bili v svojem vplivu na slovenščino $\mathrm{v}$ primerjavi z drugimi tujimi jeziki, ki imajo sklanjatve in nestalni naglas, ${ }^{72}$ prestižni.

Čeprav je SP 2001 izšel pozneje kot priročnik Antična imena po slovensko (AIS), je mogoče s primerjavo imen v obeh delih ugotoviti, da AIS kljub rešitvam, ustreznejšim za slovenščino, žal ni vplival na prevzemanje antičnih

72 »Pri prevzemanju imen iz teh jezikov/poljščine, makedonščine; op. pis./ ta naglasna mesta ohranjamo, vendar pri prevzemanju besed naglasa ne premikamo: naglašujemo torej Krákov -a (ne s Poljaki Krakóva), pa Hajdúk -a (ne kot v srbohrvaškem knjižnem jeziku Hájduk -úka ali -a).« (Toporišič, Enciklopedija slovenskega jezika, 306.) 
imen v slovenščino v SP 2001. Prenova pravopisnih pravil ponuja priložnost, da sprejmemo ponujene rešitve in tako odpravimo neskladja, neenotnosti in napake ter v duhu predloga Kajetana Gantarja in Bronislave Aubelj izločimo nepotrebne dvojnice in med zdaj ponujenimi izberemo ustreznejše, pustimo pa samo tiste, ki jih narekuje pogosta raba.

Predlogi slovenjenja v razpravi se v glavnem opirajo na AIS, pri čemer skušajo biti čim bolj sistematični in pregledni, saj se nepoznavalec starogrškega in latinskega jezika v pravilih, zapisanih v AIS, težko znajde. Nekateri, tu predstavljeni $\mathrm{v}$ petih točkah, se od AIS vendarle razlikujejo in so potrebni strokovne presoje.

1. Imena na končaj iz samoglasnika in st.gr. -as (-Cias in -Ceús) in -os (-CVos) naj imajo poslovenjeno imenovalniško osnovo in slovensko pregibanje: Górgias -gia > Górgij-a, Tejrézias -zia > Tejrézij-a; Aristéas > Aristêj-a; Dánaos -aa > Danáj-a, Peiríthoos $>$ Pejrítoj-a.

2. Imena na končaj iz soglasnika in st.gr. -as (-Cas) naj se sklanjajo tako, da $\mathrm{v}$ stranskih sklonih ohranjajo poslovenjeno imenovalniško osnovo: Epaminóndas -da > Epaminóndas -a.

3. Imena na st.gr. končaja -kles in -ZvZves naj se sklanjajo tako, da v stranskih sklonih ohranjajo poslovenjeno imenovalniško osnovo: Sófokles - $a$; Artafêrnes - $a$. Zaradi pogoste rabe drugačne osnove v stranskih sklonih naj bo rodilnik tudi na -kla in -rna: Sófokles -kla; Artafêrnes -rna.

4. Lat. končaj-CZvum naj se posloveni v-CeZv; tako se izognemo posebnosti v pregibanju: Velábrum -bra > Veláber -bra.

5. Lat. ime Cícero -óna naj se ravna po tipu Nêron (lat. rodilniška osnova na -n- je slov. imenovalniška osnova), a z možnostjo dvojničnega naglaševanja: Cíceron -óna in Cíceron -a.

Ker imamo za imenovalniško končnico samo tisti del besede, ki se v odvisnih sklonih zamenja $\mathrm{z}$ ustrezno slovensko, bi lahko v primeru st.gr. imen imeli za dvojnično stilno zaznamovano končnico v slovenščini le -es v končajih -kles in -ZvZves (točka 3). Vsa druga imena moškega spola v razpravi imajo v slovenščini bodisi ničto končnico (1. moška sklanjatev) ali končnico -a (2. ali 1. moška sklanjatev).

Predlagana pravila in izbrane zglede je mogoče prikazati $\mathrm{v}$ dveh preglednicah (gl. Dodatek); v ležečem tisku so imena, omenjena v sklepnih točkah 1-5.

\section{BIBLIOGR AFIJA}

Aubelj, Bronislava. Antična imena po slovensko. Ljubljana: Modrijan, 1997.

Gantar, Kajetan. »Nekaj misli o pisavi antičnih imen in strokovnih izrazov." Arheološki vestnik 25 (1974): 539-549.

Gigafida = www.gigafida.net (dostop: 2. 4. 2016). 
Harvey, sir Paul idr., ur. Antika. Prevod Ksenija Dolinar, Miriam Drev, Katarina Jerin, Katarina Trojar, Barbara Zupančič. Uredila Seta Knop. Ljubljana: Cankarjeva založba, 1998.

Hrovatič, Renata. Latinska imena slovenskih krajev. A-diplomska naloga. Ljubljana: Filozofska fakulteta, 1993.

Nova beseda $=$ http://bos.zrc-sazu.si/s_beseda.html (dostop: 12. 10. 2016).

SP 2001 = Jože Toporišič idr. Slovenski pravopis. Ljubljana: SAZU, Inštitut za slovenski jezik Frana Ramovša ZRC SAZU (izd.) in Založba ZRC (zal.), 2001.

eSP 2003 = Jože Toporišič idr. Slovenski pravopis. Elektronska izdaja. Ljubljana: SAZU, Inštitut za slovenski jezik Frana Ramovša ZRC SAZU (izd.) in Založba ZRC (zal.), 2003.

Toporišič, Jože. Enciklopedija slovenskega jezika. Ljubljana: Cankarjeva založba, 1992.

—. Slovenska slovnica. Maribor: Založba Obzorja Maribor, 2000. 
DODATEK: PREDLOGI ZA SLOVENJENJE IN PREGIBANJE STAROGRŠKIH IN LATINSKIH LASTNIH IMEN MOŠKEGA SPOLA

Preglednica 1: Predlog za slovenjenje in pregibanje starogrških lastnih imen moškega spola

\begin{tabular}{|c|c|c|}
\hline Pravilo o slovenjenju & $\begin{array}{l}\text { Starogrški } \\
\text { imenovalnik }\end{array}$ & $\begin{array}{l}\text { Slovenski imenovalnik } \\
\text { in rodilniška končnica }\end{array}$ \\
\hline \multicolumn{3}{|c|}{ STAROGRŠKI KONČAJ -AS } \\
\hline $\begin{array}{l}\text {-as ohranjamo v -Cas } \\
\text { (razen v -goras) }\end{array}$ & $\begin{array}{l}\text { Mídas, } \\
\text { Epameinóndas, } \\
\text { Leonídas }\end{array}$ & $\begin{array}{l}\text { Mídas -a, Epaminóndas } \\
-a \text {, Leónidas -a }\end{array}$ \\
\hline -goras slovenimo v -gora & Pythagóras & Pitágora -e in -a \\
\hline -Cias slovenimo v -Cij & Gorgías, Teiresías & Górgij-a, Tejrézij-a \\
\hline -CVias slovenimo v -Cij & $\begin{array}{l}\text { Augeías (lat. Augias), } \\
\text { Aineías (lat. Aeneas) }\end{array}$ & Ávgij -a, Enêj -a \\
\hline -Céas slovenimo v -Cej & Aristéas $^{*}$ & Arístej -a \\
\hline \multicolumn{3}{|c|}{ STAROGRŠKI KONČAJ -ES } \\
\hline \multicolumn{3}{|l|}{ Dvozložna imena (st.gr.) } \\
\hline -es ohranjamo & Áres & Áres -a \\
\hline \multicolumn{3}{|l|}{ Večzložna imena (st.gr.) } \\
\hline $\begin{array}{l}\text {-es opuščamo v: } \\
\text {-VCes } \\
\text {-CCes }\end{array}$ & $\begin{array}{l}\text { Aristotéles } \\
\text { Eukleídes [euklêjdes] } \\
\text { (lat. Euclides), } \\
\text { Oréstes }\end{array}$ & $\begin{array}{l}\text { Aristótel -a } \\
\text { Evklíd -a, Orést -a }\end{array}$ \\
\hline $\begin{array}{l}\text {-es ohranjamo v: } \\
\text {-kles } \\
\text {-ZvZves }\end{array}$ & $\begin{array}{l}\text { Sophoklês } \\
\text { Artaphérnes }\end{array}$ & $\begin{array}{l}\text { Sófokles - a } \\
\text { tudi Sófokles -kla } \\
\text { Artafêrnes -a } \\
\text { tudi Artafêrnes -rna }\end{array}$ \\
\hline \multicolumn{3}{|c|}{ STAROGRŠKI KONČAJ -IS } \\
\hline -is ohranjamo & $\begin{array}{l}\text { Dáphnis, } \\
\text { Rhadámantys }\end{array}$ & $\begin{array}{l}\text { Dáfnis -a, Radamántis } \\
\text {-a }\end{array}$ \\
\hline
\end{tabular}

* Ime je slovenjeno po analogiji z drugimi končaji s samoglasnikom (-CVos in -Ceús); od st.gr. imena Aristeús (st.gr. končaj-Ceús, slov. končaj -Cêj) se razlikuje v naglasu (Aristêj -a). 


\begin{tabular}{|c|c|c|}
\hline \multicolumn{3}{|l|}{ STAROGRŠKI KONČAJ -OS } \\
\hline \multicolumn{3}{|l|}{ Dvozložna imena (st.gr.) } \\
\hline -os opuščamo v -VCCos & $\begin{array}{l}\text { Proîtos, Sestós, } \\
\text { Lýktos, Líndos }\end{array}$ & $\begin{array}{l}\text { Prójt -a, Sést -a, Líkt } \\
\text {-a, Línd -a }\end{array}$ \\
\hline -os ohranjamo v: & & \\
\hline$-\mathrm{VCos}$ & Mínos, Lýkos & Mínos -a, Líkos -a \\
\hline $\begin{array}{l}\text {-os izjemoma opuščamo v: } \\
\text {-VCos }\end{array}$ & $\begin{array}{l}\text { Kýrrhos, Pýrrhos, } \\
\text { Týros }\end{array}$ & Kír -a, Pír -a, Tír -a \\
\hline \multicolumn{3}{|l|}{ Večzložna imena (st.gr.) } \\
\hline -os opuščamo v -Cos & Aischýlos, Epídauros & Ájshil -a, Epidáver -vra \\
\hline -os ohranjamo v -ZvZvos & $\begin{array}{l}\text { Epídamnos, } \\
\text { Mímnermos }\end{array}$ & $\begin{array}{l}\text { Epidámnos -a, } \\
\text { Mimnêrmos -a }\end{array}$ \\
\hline $\begin{array}{l}\text {-CVos, -ZvVos, } \\
\text {-CVîos, -ZvVîos } \\
\text { slovenimo v -CVj, -ZvVj }\end{array}$ & $\begin{array}{l}\text { Danaós, Peiríthoos, } \\
\text { Menélaos, } \\
\text { Amphiáraos, Hélios } \\
\text { Alkaîos, Ptolemaîos }\end{array}$ & $\begin{array}{l}\text { Dánaj -a, Pejrítoj -a, } \\
\text { Meneláj -a, Amfiaráj } \\
\text {-a, Hélij -a } \\
\text { Alkáj -a, Ptolemáj -a }\end{array}$ \\
\hline \multicolumn{3}{|c|}{ STAROGRŠKI KONČAJ -US } \\
\hline -Ceús slovenimo v -Cêj & $\begin{array}{l}\text { Aigeús, Odysseús, } \\
\text { Aristeús }\end{array}$ & $\begin{array}{l}\text { Egêj -a, Odisêj -a, } \\
\text { Aristêj -a }\end{array}$ \\
\hline \multicolumn{3}{|l|}{ STAROGRŠKI KONČAJ -ON } \\
\hline $\begin{array}{l}\text {-on je del imenovalniške } \\
\text { osnove v: } \\
\text {-Con (izjeme) } \\
\text {-CVon } \\
\text {-CVion slovenimo v } \\
\text {-CVjon }\end{array}$ & $\begin{array}{l}\text { Drákon } \\
\text { Pygmalíon } \\
\text { Herákleion }\end{array}$ & $\begin{array}{l}\text { Drákon -a } \\
\text { Pigmálion -a } \\
\text { Heraklêjon -a }\end{array}$ \\
\hline $\begin{array}{l}\text {-on } \mathrm{v} \text {-Vsion slovenimo } \mathrm{v} \\
\text {-Vzij }\end{array}$ & Elýsion & Elízij -a \\
\hline $\begin{array}{l}\text { st.gr. rodilniška osnova na } \\
\text {-nt- je slov. imenovalniška } \\
\text { osnova }\end{array}$ & $\begin{array}{l}\text { Achéron } \\
\left(\text { Achérontos }_{\mathrm{R}}\right) \\
\text { Xenophôn } \\
\left(\text { Xenophóntos }_{\mathrm{p}}\right)\end{array}$ & $\begin{array}{l}\text { Aherónt -a, Ksenofónt } \\
-\mathrm{a}\end{array}$ \\
\hline \multicolumn{3}{|l|}{ STAROGRŠKI KONČAJ -S } \\
\hline $\begin{array}{l}\text { st.gr. rodilniška osnova na } \\
\text {-nt- je slov. imenovalniška } \\
\text { osnova }\end{array}$ & $\begin{array}{l}\text { Aías }\left(\text { Aíantos }_{\mathrm{R}}\right) \text {, Átlas } \\
\left(\text { (Átlantos }_{\mathrm{R}} \text { ) }\right.\end{array}$ & Ajánt -a, Atlánt -a \\
\hline
\end{tabular}


Preglednica 2: Predlog za slovenjenje in pregibanje rimskih (antičnih) imen moškega spola

\begin{tabular}{|c|c|c|}
\hline \multicolumn{3}{|l|}{ LATINSKI KONČAJ -US } \\
\hline Pravilo o slovenjenju & Latinski imenovalnik & $\begin{array}{l}\text { Slovenski imenovalnik in } \\
\text { rodilniška končnica }\end{array}$ \\
\hline -us opuščamo v-Cus & $\begin{array}{l}\text { Bacchus (gr. } \\
\text { Bákchos), Quirinus, } \\
\text { Plautus } \\
\end{array}$ & $\begin{array}{l}\text { Bákh -a, Kvirín -a, Plávt } \\
\text {-a }\end{array}$ \\
\hline $\begin{array}{l}\text {-Cius slovenimo v -Cij } \\
\text {-CCius slovenimo v } \\
\text {-CCij (tudi } \\
\text {-stij) }\end{array}$ & $\begin{array}{l}\text { Vergilius } \\
\text { Salustius }\end{array}$ & $\begin{array}{l}\text { Vergílij -a } \\
\text { Salústij -a }\end{array}$ \\
\hline $\begin{array}{l}\text { končaj -tius (razen } \\
\text {-stius) slovenimo v -cij }\end{array}$ & Lucretius & Lukrécij-a \\
\hline $\begin{array}{l}\text { končaj-CVius } \\
\text { slovenimo v-CVj }\end{array}$ & Apuleius, Pompeius & Apulêj -a, Pompêj -a \\
\hline \multicolumn{3}{|l|}{ LATINSKI KONČAJ -UM } \\
\hline $\begin{array}{l}\text {-um opuščamo v: } \\
\text {-Cum } \\
\text {-CZvum } \\
\end{array}$ & $\begin{array}{l}\text { Saguntum } \\
\text { SR. sp } \\
\left(\text { Sagunti }_{R}\right)_{\text {Velabrum }}\end{array}$ & $\begin{array}{l}\text { Sagúnt -a } \\
\text { Veláber-bra }\end{array}$ \\
\hline $\begin{array}{l}\text {-CVum slovenimo v } \\
-\mathrm{CVj}\end{array}$ & $\begin{array}{l}\text { Herculaneum, } \\
\text { Lilybaeum (st.gr. } \\
\text { Lilýbaion) }\end{array}$ & Herkulánej -a, Lilibêj -a \\
\hline -tium slovenimo v -cij & Latium & Lácij-a \\
\hline \multicolumn{3}{|l|}{ LATINSKI KONČAJ -O } \\
\hline $\begin{array}{l}\text { lat. rodilniška } \\
\text { osnova na -n- je slov. } \\
\text { imenovalniška osnova }\end{array}$ & 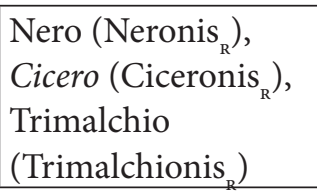 & $\begin{array}{l}\text { Nêron -a, Cíceron -óna } \\
\text { in Cíceron - } a \text {, Trimálhion } \\
\text {-óna in Trimálhion -a }\end{array}$ \\
\hline \multicolumn{3}{|l|}{ LATINSKI KONČAJ -S } \\
\hline $\begin{array}{l}\text { lat. rodilniška osnova na } \\
\text {-t- je slov. imenovalniška } \\
\text { osnova }\end{array}$ & Nepos $\left(\right.$ Nepoti $\left._{\mathrm{R}}\right)$ & Nepót \\
\hline
\end{tabular}


THE FORMS OF GREEK AND LATIN PROPER NAMES ATTRIBUTED TO THE FIRST MASCULINE SLOVENE DECLENSION

\section{Summary}

The paper analyses 170 classical Greek and 81 Latin names from the electronic edition of the normative guide Slovenski pravopis (Slovene Orthography, eSP 2003), comparing and, where necessary, partly complementing them with the forms and occasionally with the genitives found in B. Aubelj's 1997 handbook Antična imena po slovensko (Classical Names in Slovene, AIS). The focus is on the nominatives and genitives, particularly in the names retaining their original Greek and Latin endings, and on their Slovenisation. The study discusses by clusters the classical Greek endings -as (and the word-final element -goras), -es (and the word-final element -kles), -is, -os, -us, including combinations with vowels (e.g. -ias, -eus), the endings -on and -s, and the Latin endings -us (including word-final element -ius, -tius), -um (including e.g. word-final element -eum), -o, and -s. The discussion of each cluster offers a proposal for a Slovenised nominatival base and a genitival suffix, while the conclusion brings a summary of the proposals requiring new expert assessment, and two tables.

A survey of the examples and orthography rules in ${ }^{\text {eSP }} 2003$ reveals that the 'Dictionary' part contains too many doublets and inconsistencies within each classical name cluster; moreover, inconsistencies occur between the 'Dictionary' and 'Rules' parts as well. The handbook AIS, by contrast, proposes more consistent, adequate and suitable Slovenisations of proper names, which thus deserve consideration. At the same time, the differences between classical and Slovene philology turn out to be fewer than is usually claimed on the basis of individual examples.

The clusters requiring expert assessment are especially the following:

1. The names ending in a vowel (V) and the Greek -as (-Cias and -Ceús) or -os (-CVos) should be rendered with a Slovenised nominatival base and Slovene declension: Górgias -gia > Górgij -a, Tejrézias -zia > Tejrézij -a; Aristéas > Aristêj - $a$; Dánaos -aa > Danáj - $a$, Peiríthoos $>$ Pejrítoj- $a$.

2. The names ending in a consonant $(\mathrm{C})$ and the Greek -as (-Cas) should preserve in the oblique cases the Slovenised nominatival base: Epaminóndas -da > Epaminóndas - $a$.

3. The names with classical Greek word-final elements -kles and -SC (sonorant cluster) + es should preserve the Slovenised nominatival base in the oblique cases: Sófokles - $a$; Artafêrnes - $a$. Due to the frequent use of a different base in the oblique cases, the genitives in -kla and -rna should be permitted as well: Sófokles -kla; Artafêrnes -rna.

4. The Latin word-final element -CS (sonorant) + um should be Slovenised as -CeS, to avoid irregularities in the declension: Velábrum -bra > Veláber -bra.

5. The Latin name Cícero -óna should follow the Nêron type (with the Latin genitival base ending in - $\mathrm{n}$ - being used as the Slovene nominatival base), but with the possibility of variant stress placement: Cíceron -óna and Cíceron -a. 